\title{
onderjydske Aarboger
}

III. R A K K E

II. Halvbind

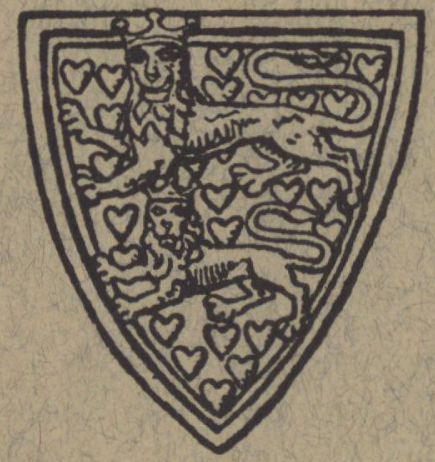

1941

Udgivet af

Historisk Samfund for Sonderjylland

\section{$A A B E N R A A$}


Spare- og Laanekassen i Aarhus

Store Torv 6

Telefon $101-292$
Horsens Landbobank A/s

Kontortid:

$91 / 2-2$ og $4-5$

HORSENS
Sparekassen for

Roskilde By og Omegn

Stiffet 1833

Telefon 9

Kontortid 9-121/2 og 14-16

\section{SONDERJYLLANDS}

KREDITFORENING

HADERSLEV

Aktieselskabet

Nordiske Kabelog Traadfabriker

Kobenhavn $F$.

Kabelværk - Traadværk Valseværk

\section{BRUUN \& SORENSEN A/S}

\section{Kgl. Hofleverandør grundlagt 1893}

I N G ENI ØR F ORR ET N I N G Varme - Sanitet - Gas - Vand - Elektricitet
KOBENHAVN

Niels Ebbesensvej 20

Tlf. C. 5036
H. A. Hansen

København 


\section{Sonderjydske Aarboger}

3. Række.

\section{1}

$\infty$

Udgive t

af

Historisk Samtund tor Sønderjylland

ved

H. Lausten-Thomsen Hans Lund

Karl N. Bock Johan Hvidtfeldt

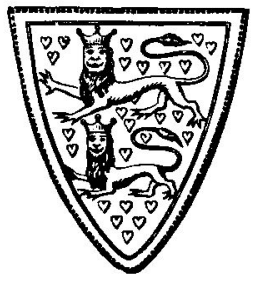

Aabenraa.

Hejmdal's Bogtrykkeri

1941 


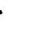




\section{INDHOLD:}

Carsten Petersen: Kirker i Tønder Provsti ...... Side $1-52$ Johan Hvidtfeld t: Bidrag til belysning af de kirkelige forhold i Vestslesvig omkring $1650 \ldots$ " $\quad 53-118$

H a n s Krog: Bemærkninger til Sønderjydske Stednavne i Aller Sogn ..................... » 119-129

J. R a b e n: Dagbog-Optegnelser fra Krigen $1864 \ldots .$. " " $130-145$

A ugust F. Schmidt: Forfatteren Hother Tolder-

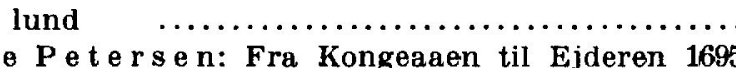

Thade Petersen: Fra Kongeaaen til Ejderen 1695 jydske Aarbøger $1939 \ldots \ldots \ldots \ldots \ldots \ldots \ldots \ldots$

Carsten Petersen: Kirker i Aabenraa Provsti ..

M. Refslund Poulsen: En Landsby i Midten af Sønderjylland (Bovlund) $\ldots \ldots \ldots \ldots \ldots$

T roels Fin k: Litteraturoversigt ..................

An meldelser:

Joh annes B r ondsted: Danmarks Oldtid (ved

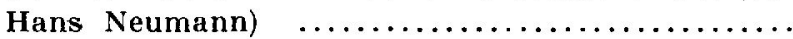

T roels F in k: Udskiftningen i Sønderjylland indtil 1770 (ved Johan Hvidtfeldt) .................. Thomas Ot to Achelis: Bürgerbuch der Stadt Harlersleben bis zum Jahre 1864. I (ved Johan Hvidtfeldt)

" $146-159$

" $160-168$

" $169-170$

" $171-203$

" 204-233

" $234-294$

" 295-299

" $300-3116$

Johan Hvidtfeldt og Hans Neumann: Beretning og Regnskab ...................... " $312-316$ 


$$
\text { - }
$$

